\title{
Proceeding
}

6th INSHS International Christmas Sport Scientific Conference, 11-14 December 2011. International Network of Sport and

Health Science. Szombathely, Hungary

\section{Technology utilization in higher education and in sport management teaching}

\author{
VALBONA CARKANJI , DHURATA BOZO
}

Sport Sciences Research Institute, University of Sport of Tirana, Albania

\begin{abstract}
Carkanji V, Bozo D. Technology utilization in higher education and in sport management teaching. J. Hum. Sport Exerc. Vol. 7, No. Proc1, pp. S202-S207, 2012. The rapid changes in technology have impacted also the education institutions. High education institutions have slowly implemented the new technology in the process of learning and the curricula. Thus, sport management educators need to better understand technology's importance to their field and as part of their efforts to achieve promotion and tenure. However, more studies are needed to research the utilization of technology in sport management courses. This study presents an overview of technology utilization in high education, the relation between the technology and learning process, and the need of implementing the technology in sports management courses. Key words: FACILITATION OF LEARNING PROCESS, IMPLEMENTATION OF NEW TECHNOLOGY, SPORTS MANAGEMENT CURSES.
\end{abstract}

Corresponding author. Sport Sciences Research Institute. Management Department. Uniersity of Sports of Tirana. Rr. Muhamet Gjollesha, Tirana, Albania.

E-mail: vcarkanji@gmail.com

6th INSHS International Christmas Sport Scientific Conference, 11-14 December 2011. International Network of Sport and Health Science. Szombathely, Hungary

JOURNAL OF HUMAN SPORT \& EXERCISE ISSN 1988-5202

(c) Faculty of Education. University of Alicante

doi:10.4100/jhse.2012.7.Proc1.23 


\section{INTRODUCTION}

The development of technology, in the last two decades, has had its positive impact on the education process. Furthermore, technology has been easily integrated to universities and it has been seen as a potential external force to enhance teaching and learning (DePauw, 1998; Massy \& Zemsky, 1994). The use of technology in education will significantly affect teaching and learning process. DePauw (1998) noted the benefits of technology in data collection, data analysis, networking, and online and virtual learning. According to Massy and Zemsky (1994) technology will demand fundamental changes from education institutions in the respond to the new technology and this transformation will be a long process. Lieberman (1960) argued that transformation in education would affect "teachers' organization, professional ethics, teachers' education, the theory and practice of teacher compensation, and many interrelationships between teachers and students, parents, communities and governmental agencies" (p. 39). Even though that technology rapidly progressing in all the science fields, by the late 1990s the educational institutions have done little changes with slow rhythm to install computers, create computing classes, or implementing computer programs (Barron \& Orwig, 1993; Jaber \& Moore, 1993). However, the first years of the new millennium found higher education institutions utilizing technology in curriculum in greater amounts. Different reports indicated that access to computers, to CDROMs, and international networking has improved and increased satisfactory.

\section{MATERIAL AND METHODS}

The authors conducted a literature review to summarize and synthesize the arguments and ideas about the utilization of technology in higher education. This review reports the possible advantages of technology in relation with teaching and learning. The main question discussed, regarding implementation of technology in learning process, has been: to what degree contribute the use of technology to increase the learning productivity? (Massy \& Zemsky, 1994; Swayer, 1993).

We applied one exclusion criteria: The articles that are not about sports higher education.

\section{RESULTS}

The literature review on utilization of the technology in universities has found issues such as: facilitation of academic learning, factors influencing faculty use of technology, barriers of technology implementation in curricula, methods of integrating technology into the curriculum, the technological learning environment, and the current status of technology-supported learning (Wilson, 2008).

\section{Facilitation of Academic Learning}

The use of technology in the course has allowed teachers and students for a productive communication, teachers have posted assignments, lecture notes, projects, recent information and as a result students have increased their interest for the course. Spinelli (2001) argued that the professors demonstrate the material with an overhead computer presentation and the student could also practice the exercises concurrently on their computers. Furthermore, audio-video technology or conference calls have create the possibility for both, teachers and students, to logon from any location in the world and also bring into the classroom expert from the field. Deden and Carter (1996) noted that professors would be using more efficiently the lecture time and students through it, would be exposed to technology as it is applied in the real world. Technology allows faculty to accommodate individual differences in student goals, learning 
style, and abilities, while providing improved convenience for both students and faculty on an "any time, any place basis (Massy \& Zemsky, 1994).

On the other side, there are opposite voices that technology is costly to implement into the classroom. Young (2004) suggested that technology is more an administrative benefit than it facilitates learning process. Students, through the technology, have access to resources, easy communication with professors, and collaboration possibilities but these do not influence the enhancement of the student learning (Zisow, 2000; Bauer, Reese, \& McAllister, 2003). Additionally, the researchers have discussed the technology in term of students 'grade performance. However, the connection between technology and learning has been seen under its usefulness in the learning process (Smith, Higgins, Wall, \& Miller, 2006).

\section{Technology's Cost-Benefit}

One of the concerns about the technology is that the benefits gains from it do not justify its high cost. For example, students have stated that technology has had little impact on the teaching of their professors (Young, 2004). Also, the students interviewed from Spinelli (2001) stated that in traditional classroom they were enabled to better understand the principles of statistics, because of the use of calculation while the students who were more computer literate enjoyed the aspect of using the statistical software to obtain answers. Furthermore, students face computer challenge skills and instead of concentrating to the lecture they may lose time to learn to utilize the software. According to Garrett (1997) students enhance their ability to be competitive in a "wired" world. Use of technology decreases the face-to-face interaction in the classroom. Spinelli (2001) studied two different groups of students who learned in traditional classroom and computer base classroom. The traditional learning students communicate and discuss to each other while computer based students lacked of communication. As soon as they entered the classroom, they concentrated on the computer and started working independently. Neal (1998) stated that the communication involved in addressing peers face-to-face in decision-making process is different than that done through technological means.

As far as concerned the sport management education, Cuneen (2004) noted that education faces students who "wish to be taught rather than inspired and wish to buy information and those single skills that will make them excel in the workplace at a fast rate" (p. 3). This statement match with Grasha and YangarberHicks (2000) who stated that this generation of students is not suitable for technologically-based courses.

Based on articles reviewed above, the technology facilitation of learning "lies not in the decision to use technology but in the methods by which technology has been implemented" (Wilson, 2008, p. 27). Thus, technology can facilitate learning.

Factors Influencing Faculty Use of Technology

The implement of technology, under the teachers' point of view, must have pedagogical benefit. Wilson (2008) has considered (see Table 1) thirteen factors which influence faculty's use of technology based on the research literature. 
Table 1. Factors influencing faculties' use of technology.

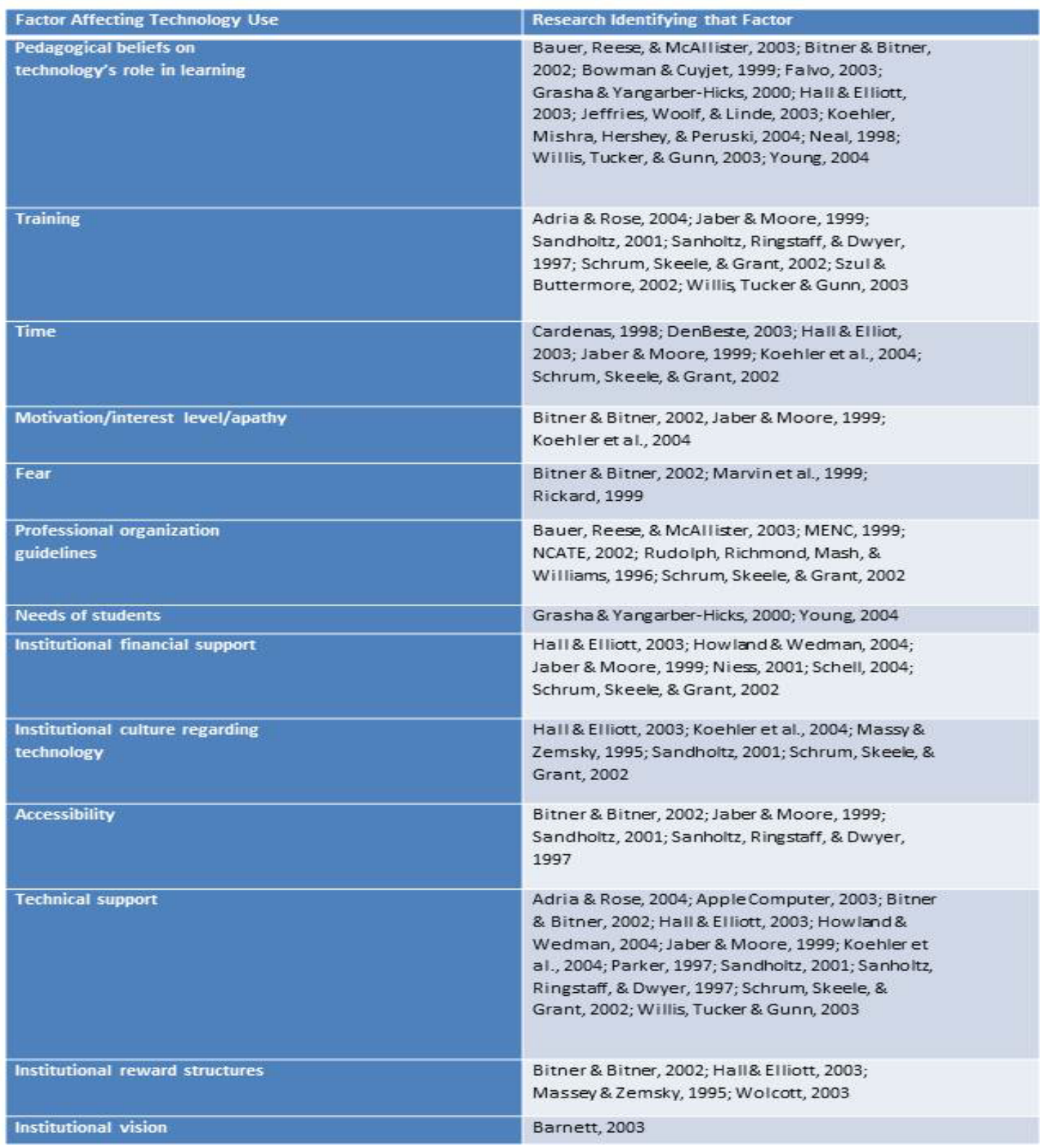

Recently, teachers have replaced the traditional teaching methods with computer technologies. Traditional methods of instruction have been somewhat replaced by more convenient and user-friendly computer technologies (Wilson, 2008). Teachers need to be train how to utilize the technology in the learning process and how to benefit by integrating it even in curricula. The fact is that integration of technology in curricula and classroom is time consuming and teachers see it as one of the biggest challenges (Sandholtz, 2001). When they are asked to change their teaching methods some teachers are skeptic about it. Thus, to overcome these difficulties teacher need motivation and commitment to implement technology in the learning process. 


\section{DISCUSSION AND CONCLUSION}

The studies in the sport management literature have found that the literature needs increased study of technology, its impact in their discipline, and especially, faculty experiences with technology (Dawson, 2006; Wilson, 2008). Thus, sport management educators need to better understand technology's importance to their field and as part of their efforts to achieve promotion and tenure (O'Meara, 2005). Students have shown interest in use of technology in classroom and they can benefit in two areas: course management software and online delivery content (Wilson, 2008). Turner (2004) stated that use of course management software increases efficiency in the administration of courses and enhance delivery of information to students. Bennett (2002) has compared the students of the traditional course with students on the online course and the results have revealed that online students were more satisfied with their course.

On the other side, students have been concerned about the online quizzes and social interaction with peers (Bennett, 2002). Different authors have been concerned with the neglect of technology utilization in management course. Teachers have ignored the technology in sport management and its importance for preparing successful sport managers (Bennett, 2002). However, few researchers have studied the technology utilization in sport management courses and as a result; the need for deeper research in curricula in sports management and the ability of sports management students are much needed.

\section{REFERENCES}

1. ANDREW DP, PERDERSEN MP, MCEVOY DC. Evolution of sport management research. USA: Champaign, IL. 2011.

2. BARRON AE, ORWIG GW. New technologies for education. Englewood, CO: Libraries Unlimited. 1993

3. BAUER WI, REESE S, MCALLISTER PA. Transforming music teaching via technology: The role of professional development. Journal of Research in Music Education. 2003; 51(4):289-301.

4. BENENETT G. Web-based instruction in sport management. Sport Management Review. 2002; 5(1):46-68.

5. CUNEEN J. Managing program excellence during our transition from potential to merit. Journal of Sport Management. 2004; 18:1-12.

6. CUNEEN J, SIDWELL MJ. Evaluating and selecting sport management undergraduate programs. Journal of College Admissions. 1998; 158:6-13.

7. DAWSON K. Teacher inquiry: A vehicle to merge prospective teachers' experience and reflection during curriculum-based, technology-enhanced field experiences. Journal of Research on Technology in Education. 2006; 38(3):265-292.

8. DEDEN A, CARTER VK. Using technology to enhance students' skills. New Directions for Higher Education. 1996; 24:81-92.

9. DEPAUW KP. Futuristic perspectives for kinesiology and physical education. Quest. 1998; 50:1-8.

10. GRASHA AF, YANGARBER-HICKS N. Integrating teaching styles and learning styles with instructional technology. College Teaching. 2000; 48(1):2-10.

11. JABER WE, MOORE DM. A survey of factors which influence teachers' use of computer-based technology. International Journal of Instructional Media. 1999; 26(3):253-266.

12. LIEBERMAN M. What the problem is not. In the future of public education. University of Chicago Press. 1960. 
13. MASTERALEXIS LP, BARR CA, HUMNS MA. Principles and practice of sport management. Gaithersburg, Maryland: Aspen. 1998.

14. MASI AC, WINER LR. A university-wide vision of teaching and learning with information technologies. Innovations in Education and Teaching International. 2005; 42(2):147-155.

15. MASSY FW, ZEMSKY R. Using information technology to enhance academic productivity. Accessed November 8, 2011, from http://net.educause.edu/ir/library/html/nli0004.html

16. NEAL E. Using technology in teaching: We need to exercise healthy skepticism. Chronicle of Higher Education. 1998; 19:B4-B5.

17. O'MEARA KA. Encouraging multiple forms of scholarship in faculty award systems: Does it make a difference? Research in Higher Education. 2005; 46(5):479-510.

18. SAWER TH. Sport management: Where should it be housed. Journal of Physical Education, Recreation \& Dance. 1993; 64(9):4-5.

19. SANDHOLTZ JH. Learning to teach with technology: A comparison of teacher development programs. Journal of Technology and Teacher Education, 2001; 9(3):349-374.

20. SMITH HJ, HIGGINS S, WALL K, MILLER J. Interactive whiteboards: Boon or bandwagon? A critical review of the literature. Journal of Computer Assisted Learning. 2006; 21:91-101.

21. SPINELLI MA. The use of technology in teaching business statistics. Journal of Education for Business. 2001; 77(1):41-44.

22. TURNER BA, JORDAN JS, SAGAS M. Factors affecting response rates in survey research: The case of intercollegiate coaches. Applied Research in Coaching \& Athletics Annual. 2006; 21:211237.

23. WILSON LS. Examining technology utilization in sport management curricula and teaching (Doctoral dissertation) Available from Proquest Dissertation \& Theses database. (UMI No. 3324110) 2008.

24. YOUNG JR. Students say technology has little impact on teaching. The Chronicle of Higher Education. 2004; 50(49):28.

25. ZISOW MA. Teaching style and technology. Tech Trends. 2000; 44(4):36-38. 